\title{
PENGARUH MODEL COOPERATIVE PROBLEM SOLVING TERHADAP KEMAMPUAN PEMECAHAN MASALAH SISWA PADA MATERI TEKANAN
}

\author{
${ }^{1 *}$ Kartika Eka Kusuma Wardani, ${ }^{2}$ Tomo Djudin, ${ }^{3}$ Syukran Mursyid \\ 1,2,3 Universitas Tanjungpura, Kota Pontianak, Indonesia
}

*Email Korespondensi: kartikaeka857@gmail.com

\section{INFO ARTIKEL}

Diterima 02 November 2020

Direvisi : -

Dipublikasikan : 31 Januari 2021

\begin{abstract}
The aim of this research was to determine the effectiveness of the implementation of the Cooperative Problem Solving model in enhancing the problem solving skills of students of SMPN 3 Sungai Raya in the pressure of solids. The research forms used was quasy experimental design with pretest-posttest control group design. The sample was students VIII G as an experimental class and VIII E was the control class which drawn by using intact group. The instrument used 5 essay questions. The result showed that there was no difference in the student problem solving skills of the control class and experimental classes before being given the implementation of Cooperative Problem Solving model and conventional learning $(p>0,5)$. There was difference in the student problem solving skills of the control class and experimental classes after being given the implementation of Cooperative Problem Solving model and conventional learning $(\mathrm{p}<0,5)$. Implementation of Cooperative Problem Solving model effective to improve the student problem solving skills with effect size 1,89 (high category).
\end{abstract}

Kata Kunci: Keywords: Cooperative Problem Solving, Problem Solving, Pressure

\section{Pendahuluan}

Beberapa keterampilan yang harus dikuasai oleh setiap orang agar berhasil menghadapi tantangan, permasalahan, kehidupan di abad ke-21 antara lain: (1) kemampuan berfikir kritis dan pemecahan masalah, (2) kolaborasi dan kepemimpinan, (3) ketangkasan dan kemampuan beradaptasi, (4) inisiatif dan berjiwa entrepreneur, (5) kemampuan berkomunikasi efektif baik secara oral maupun tertulis, (6) kemampuan mengakses dan menganalisis informasi, serta (7) memiliki rasa ingin tahu dan imajinasi (Wagner, 2010). Oleh karena itu, berbagai Negara di dunia berusaha merumuskan paradigma pendidikan di abad 21 untuk mmeningkatkan daya saing (Mukminan, 2014), salah satunya Indonesia. Di Indonesia, kesadaran mengenai pentingnya keterampilan abad ke-21 dapat ditemukan dalam dokumen yang dikeluarkan oleh BSNP tahun 2010. Pada dasarnya, berbagai keterampilan yang diperlukan di abad ke-21 sudah diadaptasi dalam sistem pendidikan di Indonesia melalui kurikulum 2013 (Andrian \& Rusman, 2019). Paradigma pembelajaran abad ke-21 menekankan kemampuan peserta didik dalam mencari tahu dari berbagai sumber, merumuskan permasalahan, berfikir analitis dan bekerjasama, serta berkolaborasi dalam memecahkan masalah (Kemdikbud, 2014). Salah satu keterampilan dan kompetensi yang diharapkan untuk dicapai dalam proses pendidikan adalah kemampuan pemecahan masalah.

Kemampuan pemecahan masalah harus dibekalkan kepada peserta didik, bukan hanya digunakan untuk membantu peserta didik menyelesaikan konsep matematis, menjawab soal tentang pembelajaran yang memerlukan aspek kognitif (Masfuah \& Ika, 2018), tetapi juga digunakan peserta didik agar terbiasa menghadapi permasalahan dalam kehidupan yang semakin kompleks (Prastiwi, 2018) serta dapat bersaing secara global (Dewi et al, 2007). Oleh karena itu, kemampuan ini sangat penting dikuasai peserta didik. 
Fisika merupakan salah satu mata pelajaran yang erat kaitannya dengan pemecahan masalah (Sujarwanto et al, 2014; BSNP, 2006; Aliefia \& Mayasari, 2018; dan Heller, 2010). Materi fisika tidak dapat diajarkan dengan cara menghafal, melainkan perlu bernalar dan memahami konsep (Lona et al, 2013). Pada hakikatnya, pemecahan masalah merupakan belajar berfikir (learning to think) atau belajar bernalar (learning to reason) dengan mengaplikasikan pengetahuan-pengetahuan yang diperoleh sebelumnya untuk memecahkan masalah-masalah yang baru (Anditia, 2016).

Pada kenyataannya, pemecahan masalah menjadi kendala utama dalam pembelajaran fisika (Taale, 2010). Hal ini disebabkan karena yang terjadi di sekolah pada umumnya masih menggunakan model pembelajaran konvensional, yaitu guru menjadi acuan dalam menyampaikan materi (Murtiningsih, 2004). Sehingga peserta didik cenderung mendengar dan mencatat apa yang disampaikan oleh guru dan tidak diberikan kesempatan untuk menentukan konsep yang akan digunakan. Peserta didik yang diberikan soal-soal fisika cenderung menggunakan persamaan matematis tanpa menganalisis terlebih dahulu, menebak rumus, dan menghafal contoh soal yang telah dikerjakan sebelumnya (Azizah, 2016). Ikhwanuddin (2010) menambahkan kurangnya kemampuan pemecahan masalah peserta didik meliputi, (1) pemahaman yang lemah terhadap prinsip dan aturan fisika, (2) kurang dalam memahami soal, dan (3) tidak memiliki motivasi untuk belajar fisika.

Rendahnya kemampuan pemecahan masalah peserta didik dapat dilihat melalui data penelitian internasioal Organization Of Economic And Development's (OECD) dalam Program For International Student Assesment (PISA) tahun 2015. Data penelitian tersebut menunjukkan bahwa kemampuan peserta didik di Indonesia dalam menyelesaikan soal-soal yang menuntut kemampuan analisis, evaluasi, kreasi, serta logika dan penalaran masih sangat kurang (Kurniati et al, 2016). Markawi (2015) juga berpendapat bahwa peserta didik di Indonesia hanya dapat menjawab soal hapalan dan tidak dapat menjawab soal yang memerlukan penalaran.

Berdasarkan hasil studi pendahuluan di SMP Negeri 3 Sungai Raya melalui wawancara dengan guru, didapatkan bahwa peserta didik kesulitan memahami konsep dan menyelesaikan soal pada materi tekanan. Peserta didik juga kesulitan menyelesaikan soal-soal tekanan yang berbeda dengan contoh soal, sehingga peserta didik belum memahami hubungan antara gaya dan luas permukaan terhadap besarnya tekanan. Masalah lain yang dihadapi adalah dalam pembelajaran fisika masih menggunakan model pembelajaran konvensional, sehingga tidak banyak peserta didik berperan aktif dalam proses pembelajaran dan kurang menarik perhatian peserta didik. Padahal menurut Slameto (2015), proses pembelajaran yang berpusat pada guru hanya akan membuat guru semakin cerdas, sedangkan peserta didik mendapatkan pengalaman mendengarkan saja.

Untuk meningkatkan kemampuan pemecahan masalah peserta didik, perlu didukung dengan penggunaan model yang tepat. Salah satu model yang dapat digunakan untuk meningkatkan kemampuan pemecahan masalah peserta didik adalah model Cooperative Problem Solving. Model Cooperative Problem Solving merupakan perpaduan antara strategi Problem Solving dan model Cooperative Learning yang menugaskan peserta didik untuk menyelesaikan masalah secara berkelompok dengan cara mendiskusikan masalah yang diberikan, membantu memecahkan masalah, dan saling berbagi tugas (Heller, 2010).

Menurut Heller (2010), model Cooperative Problem Solving seperti permainan catur yang memiliki tiga bagian, yaitu opening moves, middle game, dan end game serta lima langkah pemecahan masalah disetiap tahapan tersebut. Tahap opening moves merupakan tahap awal dari model Cooperative Problem Solving yang menentukan pola pikir awal peserta didik. Tahap ini juga dimasukkan langkah pemecahan masalah yang pertama, yaitu focus on the problem (fokus terhadap masalah). Tahap middle game merupakan kegiatan belajar yang artinya peserta didik mulai berkolaborasi memecahkan masalah yang diberikan. Tahap ini dimasukkan langkah pemecahan masalah yang kedua sampai keempat, yaitu describe the physics (mendeskripsikan ke bentuk fisika), plan a solution (merencanakan solusi), dan execute the plan (menjalankan rencana). Tahap end game merupakan bagian akhir dari model Cooperative Problem Solving yang bertujuan untuk memberikan kesimpulan dari kegiatan belajar yang telah dilakukan, pada tahap ini dimasukkan langkah pemecahan masalah yang terakhir, yaitu evaluate the answer (mengevaluasi jawaban).

Model Cooperative Problem Solving tidak hanya menuntut peserta didik untuk dapat memecahkan masalah yang diberikan oleh guru, tetapi juga belajar mengorganisir kemampuan mereka dalam kelompoknya masing-masing (Prasetyoningrum et al, 2014). Selain itu, pembelajaran yang dilakukan secara kooperarif dapat merealisasikan kebutuhan peserta didik dalam belajar, berfikir, memecahkan masalah, dan mengintegrasi kemampuan dalam keterampilan (Khotimah, 2016).

Penelitian menggunakan model Cooperative Problem Solving sudah dilakukan sebelumnya, seperti model Cooperative Problem Solving dapat meningkatkan kemampuan pemecahan masalah peserta didik (Avico et al, 2019), 
aktivitas belajar dan hasil belajar (Sari et al, 2018), serta kemampuan komunikasi ilmiah dan pemahaman konsep peserta didik (Kulsum \& Nugroho, 2014). Penggunaan model Cooperative Problem Solving untuk meningkatkan kemampuan pemecahan masalah peserta didik tergolong sedikit, seperti penelitian yang dilakukan oleh Sari et al (2018), Avico et al (2019), dan Ratnaningdyah (2017). Penelitian yang dilakukan sebelumnya menggunakan satu dan dua kelas, namun kelas pembanding tidak diberikan perlakuan, selain itu, penelitian sebelumnya tidak menganalisis berdasarkan indikator pemecahan masalah. Untuk itu, penelitian ini menggunakan dua kelas sebagai sampel dengan kelas pembanding diberikan perlakuan model pembelajaran konvensional.

Berdasarkan tinjauan di atas, maka dilakukan penelitian dengan model Cooperative Problem Solving untuk melihat peningkatan kemampuan pemecahan masalah peserta didik dalam menyelesaikan soal-soal tekanan di SMP Negeri 3 Sungai Raya.

\section{Metode Penelitian}

Desain penelitian ini menggunakan quasy eksperimental design dengan rancangan pretest-posttest control group design. Seluruh peserta didik kelas VIII di SMP Negeri 3 Sungai Raya tahun ajaran 2019/2020 merupakan populasi dalam penelitian ini. Sampel yang digunakan dalam penelitian ini, yaitu: Kelas VIII G sebagai kelas eksperimen dan kelas VIII E sebagai kelas kontrol, yang dipilih melalui teknik intact group.Pengumpulan data yang digunakan dalam penelitian ini yaitu dengan teknik pengukuran berupa 5 soal essai tentang tekanan dan dinilai berdasarkan 5 indikator pemecahan masalah, yakni fokus terhadap masalah, mendeskripsikan kebentuk fisika, merencanakan solusi, menjalankan rencana, dan mengevaluasi jawaban. Langkah-langkah yang dilakukan dalam penelitian ini meliputi:

Tahap Persiapan

Langkah-langkah pada tahap persiapan yaitu sebagai berikut: (1) merencanakan penelitian dengan membuat jadwal penelitian secara kasar; (2) menentukan tempat penelitian, (3) melakukan observasi ke sekolah yang diteliti; (4) menyusun desain penelitian; (5) menyiapkan instrument penelitian berupa soal-soal pretest dan posttest, lembar kerja peserta didik (LKPD), serta rencana pelaksanaan pembelajaran (RPP); (5) seminar desain penelitian; (6) revisi desain penelitian; (7) melakukan validasi instrument penelitian; (8) melakukan uji soal yang digunakan dalam penelitian; (9) membuat jadwal kegiatan pembelajaran.

Tahap Pelaksanaan

Langkah-langkah pada tahap pelaksanaan yaitu sebagai berikut: (1) melaksanakan penelitian yang diawali dengan pretest di kelas eksperimen dan kelas kontrol; (2) melaksanakan kegiatan pembelajaran menggunakan model Cooperative Problem Solving di kelas eksperimen; (3) melaksanakan kegiatan pembelajaran menggunakan model pembelajaran konvensional di kelas kontrol; (4) memberikan tes akhir (posttest) setelah kegiatan pembelajaran di kelas eksperimen dan kelas kontrol.

Tahap Akhir

Langkah-langkah pada tahap akhir yaitu sebagai berikut: (1) menganalisis data berdasarkan hasil pretest dan posttest; (2) menarik kesimpulan berdasarkan hasil analisis data; (3) menyusun laporan penelitian; (4) memaparkan laporan hasil penelitian.

\section{Hasil dan Pembahasan}

\subsection{Hasil}

Perbedaan Kemampuan Pemecahan Masalah Peserta Didik Sebelum Diberikan Perlakuan Hasil kemampuan pemecahan masalah yang terdiri dari kelas eksperimen dan kelas kontrol ditunjukkan melalui hasil pretest peserta didik yang disajikan pada Tabel 1.

Tabel 1. Persentase Kemampuan Pemecahan Masalah Pretest

\begin{tabular}{lcc}
\hline \multirow{2}{*}{ Indikator Pemecahan Masalah } & \multicolumn{2}{c}{ Persentase } \\
\cline { 2 - 3 } & Eksperimen & Kontrol \\
\hline Fokus terhadap masalah & $2 \%$ & $4 \%$ \\
\hline $\begin{array}{l}\text { Mendeskripsikan ke bentuk } \\
\text { fisika }\end{array}$ & $8 \%$ & $10 \%$ \\
\hline
\end{tabular}




\begin{tabular}{ccc}
\hline Merencanakan solusi & $2 \%$ & $13 \%$ \\
\hline Menjalankan rencana & $15 \%$ & $15 \%$ \\
\hline Mengevaluasi jawaban & $23 \%$ & $10 \%$ \\
\hline Rata-rata & $10 \%$ & $10,4 \%$ \\
\hline
\end{tabular}

Berdasarkan tabel 1, rata-rata persentase kemampuan pemecahan masalah pretest di kelas eksperimen 10\% dan di kelas kontrol 10,4\% mengindikasikan bahwa tidak terdapat perbedaan kemampuan pemecahan masalah awal peserta didik kelas eksperimen dan kelas kontrol, sehingga perlu dibuktikan dengan uji statistik Mann Whitney untuk membuktikan asumsi bahwa tidak terdapat perbedaan kemampuan pemecahan masalah awal peserta didik. Pengujian data dengan Mann Whitney terhadap skor pretest kelas eksperimen dan kelas kontrol diperoleh $p>0,5$. Oleh karena itu, dapat dikatakan bahwa tidak terdapat perbedaan kemampuan pemecahan masalah peserta didik pada kelas eksperimen dan kelas kontrol sebelum diberikan penerapan model Cooperative Problem Solving dan model pembelajaran konvensional.

Perbedaan Kemampuan Pemecahan Masalah Peserta Didik Setelah Diberikan Perlakuan

Hasil kemampuan pemecahan masalah setelah diberikan perlakuan dilihat melalui perolehan skor posttest peserta didik kelas eksperimen dan kelas kontrol yang disajikan pada tabel 2 sebagai berikut:

Tabel 2. Persentase Kemampuan Pemecahan Masalah Posttest

\begin{tabular}{lcc}
\hline \multirow{2}{*}{ Indikator Pemecahan Masalah } & \multicolumn{2}{c}{ Persentase } \\
\cline { 2 - 3 } & Eksperimen & Kontrol \\
\hline Fokus terhadap masalah & $10 \%$ & $5 \%$ \\
\hline Mendeskripsikan ke bentuk & $47 \%$ & $15 \%$ \\
fisika & $60 \%$ & $27 \%$ \\
\hline Merencanakan solusi & $60 \%$ & $18 \%$ \\
\hline Menjalankan rencana & $29 \%$ & $16 \%$ \\
\hline Mengevaluasi jawaban & $41,2 \%$ & $16,2 \%$ \\
\hline \multicolumn{1}{c}{ Rata-rata } & & .
\end{tabular}

Berdasarkan tabel 4.2, rata-rata persentase kemampuan pemecahan masalah posttest di kelas eksperimen $41,2 \%$ dan di kelas kontrol 16,2\% mengindikasikan bahwa terdapat perbedaan kemampuan pemecahan masalah akhir peserta didik kelas eksperimen dan kelas kontrol, sehingga perlu dibuktikan dengan uji statistik Independent Sample T-Test untuk membuktikan asumsi bahwa terdapat perbedaan kemampuan pemecahan masalah akhir peserta didik. Pengujian data dengan Independent Sample T-Test terhadap skor posttest kelas eksperimen dan kelas kontrol diperoleh $p<0,5$. Oleh karena itu, dapat dikatakan bahwa terdapat perbedaan kemampuan pemecahan masalah peserta didik pada kelas eksperimen dan kelas kontrol setelah diberikan penerapan model Cooperative Problem Solving dan model pembelajaran konvensional.

Efektivitas Pembelajaran

Untuk mengetahui efektivitas pengaruh model Cooperative Problem Solving dalam meningkatkan kemampuan pemecahan masalah peserta didik tentang materi tekanan digunakan perhitungan menggunakan rumus effect size cohend's. Hasil secara keseluruhan ditunjukkan pada tabel 3 sebagai berikut:

Tabel 3. Nilai Effect Size Cohen

\begin{tabular}{|c|c|c|c|c|c|}
\hline \multicolumn{2}{|c|}{ Rata-rata } & \multicolumn{2}{|c|}{ Standar Deviasi } & $S_{\text {pooled }}$ & d \\
\hline Eksperimen & Kontrol & Eksperimen & Kontrol & 1308 & 189 \\
\hline 40,94 & 16,19 & 17,46 & 6,97 & 13,00 & 1,09 \\
\hline
\end{tabular}

Berdasarkan tabel 3, diperoleh hasil perhitungan effect size sebesar 1,89 (kategori tinggi). Dengan demikian, dinyatakan bahwa efektivitas model Cooperative Problem Solving dikategorikan tinggi dalam meningkatkan kemampuan pemecahan masalah peserta didik dibanding kelas kontrol. 


\subsection{Pembahasan}

\section{Perbedaan Kemampuan Pemecahan Masalah Peserta Didik Sebelum Diberikan Perlakuan}

Berdasarkan temuan pretest, diamati lima indikator pemecahan masalah, yaitu fokus terhadap masalah, mendeksripsikan ke bentuk fisika, merencanakan solusi, menjalankan rencana, dan mengevaluasi jawaban. Pretest dilakukan untuk menentukan kemampuan pemecahan masalah awal peserta didik apakah tinggi, sedang, dan rendah serta memiliki kemampuan yang sama atau tidak.

Tabel 1 menunjukkan bahwa kemampuan pemecahan masalah awal peserta didik tergolong rendah. Rendahnya hasil awal peserta didik dikarenakan kedua kelas belum diberikan pembelajaran tentang materi tekanan, sehingga tidak dapat menyelesaikan soal dengan baik. Kedua kelas juga belum dikenalkan menyelesaikan soal menggunakan langkah-langkah pemecahan masalah, sehingga jika diamati dari hasil pretest pada tahap mengevaluasi jawaban memperoleh persentase lebih tinggi dibanding indikator lainnya, sebab peserta didik cenderung menyimpulkan hasil akhir. Namun, secara keseluruhan hasil pretest yang diperoleh peserta didik kelas eksperimen dan kelas kontrol tergolong rendah. Seperti yang dinyatakan oleh Ramadhan (2020) bahwa rendahnya hasil awal yang diperoleh peserta didik merupakan hal wajar, karena peserta didik belum mempelajari materi yang di teskan.

Perbedaan Kemampuan Pemecahan Masalah Peserta Didik Setelah Diberikan Perlakuan

Dari tabel 2, hasil kemampuan pemecahan masalah setelah kegiatan pembelajaran pada kelas eksperimen dan kelas kontrol berbeda signifikan, dalam artian terdapat perbedaan kemampuan pemecahan masalah peserta didik antara kelas eksperimen dan kelas kontrol.

Pada indikator pertama, yaitu fokus terhadap masalah jawaban peserta didik kelas eksperimen dan kelas kontrol belum dapat menggambarkan permasalahan dalam soal dengan baik. Dapat dilihat melalui persentase kedua kelas tergolong sangat rendah, peserta didik belum terbiasa menyelesaikan soal menggunakan prosedur pemecahan masalah, hal ini dikarenakan peserta didik selama belajar di sekolah terbiasa diberi pelajaran dan tidak menyelesaikan secara mandiri (Prastiwi, 2018). Peserta didik juga cenderung mengabaikan menggambarkan masalah sebagai salah satu dari bentuk repesentatif kualitiatif (Coleman, 2011).

Pada indikator kedua, yaitu mendeskripsikan ke bentuk fisika skor yang diperoleh kelas eksperimen meningkat signifikan dibanding kelas kontrol. Peserta didik kelas eksperimen yang telah diajarkan dengan langkah pemecahan masalah dapat menuliskan apa saja yang diketahui dan ditanyakan sehingga mengarah kepada konsep fisika. Peserta didik kelas kontrol juga dapat menuliskan apa saja yang diketahui dan ditanyakan, namun kurang tepat. Sehingga secara keseluruhan peserta didik kelas eksperimen lebih memahami soal dibanding kelas kontrol. Lestari (2019) menyatakan bahwa pada langkah ini membantu peserta didik untuk teliti dalam memahami soal.

Pada indikator ketiga, yaitu merencanakan solusi skor yang diperoleh peserta didik kelas eksperimen lebih tinggi dibanding kelas kontrol. Hal ini disebabkan karena peserta didik pada kelas eksperimen dapat menentukan rencana penyelesaian soal dengan cukup baik berdasarkan tahapan sebelumnya, sehingga berdampak dalam penyelesaian soal hingga menemukan jawaban yang benar.

Pada indikator keempat, yaitu menjalankan rencana, pada tahap ini peserta didik menerapkah langkah-langkah penyelesaian pada tahap sebelumnya yang menentukan peserta didik untuk memulai perhitungan. Peserta didik pada kelas eksperimen pada tahap sebelumnya merencanakan penyelesaian masalah dengan cukup baik, sehingga dapat menyelesaikan soal hingga menemukan hasil akhir dengan benar. Gock \& Silai dalam Susiana et al (2017) menyatakan bahwa pada tahap ini peserta didik menerapkan langkah-langkah pemecahan masalah sesuai rencana pada tahap sebelumnya.

Pada indikator kelima, yaitu mengevaluasi jawaban perolehan skor peserta didik pada kelas eksperimen lebih tinggi dibanding peserta didik pada kelas kontrol, namun masih tergolong rendah. Rendahnya pada tahap ini disebabkan karena sebagian peserta didik tidak memberikan kesimpulan dan lebih mengutamakan hasil perhitungan. Hal ini disebabkan karena peserta didik tidak terbiasa memberikan kesimpulan bagaimana hasil perhitungan didapat. Padahal pada tahap ini penting untuk memberikan pemahaman kepada peserta didik mengenai materi fisika yang telah diajarkan. Seperti yang dinyatakan oleh Susiana et al (2017) bahwa dalam memberikan kesimpulan dapat membantu peserta didik dalam mengetahui proses mendapatkan hasil. 
Secara keseluruhan dalam memecahkan masalah peserta didik kelas eksperimen memperoleh skor lebih tinggi dibanding kelas kontrol, meskipun kedua kelas mengalami peningkatan dari hasil tes awal. Kelas kontrol diberikan pengajaran menggunakan model pembelajaran konvensional sehingga guru cenderung lebih aktif selama kegiatan belajar dan peserta didik cenderung mendengarkan dan mencatat apa yang disampaikan oleh guru. Proses pembelajaran pada kelas kontrol bersifat teacher centered. Peserta didik tidak diberikan kesempatan untuk menemukan sendiri konsep yang dipelajari dan cenderung pasif. Hartato \& Abdurrahansyah (2009) menyatakan bahwa proses pembelajaran yang berpusat pada guru (teacher centered) hanya akan membuat guru semakin cerdas sedangkan peserta didik hanya memperoleh pengalaman mendengarkan paparan dari guru, sehingga peserta didik kesulitan dalam memahami materi yang diberikan. Wajar saja jika peroleh skor peserta didik kelas kontrol hanya mengalami peningkatan sebesar 6\% dari tes awal dan selisih 25\% dari hasil posttest kelas eksperimen.

Peserta didik kelas eksperimen diberikan pengajaran menggunakan model Cooperative Problem Solving, artinya proses pembelajaran kelas eksperimen berlangsung secara kooperatif dengan menerapkan prinsip-prinsip pemecahan masalah (Trisnawati, 2017). Penerapan model Cooperative Problem Solving membuat peserta didik berperan aktif selama kegiatan belajar-mengajar, sehingga proses pembelajaran bersifat student centered yang mengakibatkan hasil kemampuan pemecahan masalah peserta didik mengalami peningkatan yang signifikan (Nurcahyo et al, 2017).

Model Cooperative Problem Solving memiliki tiga tahapan, yaitu opening moves, middle game, dan end game. Pada kegiatan awal pembelajaran atau opening moves, peserta didik dibangkitkan rasa antusiasnya untuk mengikuti kegiatan belajar melalui motivasi sederhana tentang fenomena tekanan dalam kehidupan sehari-hari. Setelah rasa antusias peserta didik meningkat, peneliti mulai memberitahukan kepada peserta didik bahwa mereka akan mempelajari materi tekanan serta kapan dan bagaimana menerapkan prinsip tekanan tersebut. Peneliti memberitahukan kepada peserta didik untuk menyelesaikan masalah yang diberikan secara berkelompok dan memberitahukan waktu yang diperlukan peserta didik untuk menyelesaikan masalah tersebut, sebab opening moves merupakan tahap awal dari model Cooperative Problem Solving yang menentukan pola pikir awal peserta didik (Heller, 2010). Membangun pola pikir awal peserta didik penting dalam kegiatan belajar, karena pola pikir merupakan inti dari pikiran manusia dimana fungsi otak sebagai pembuat keputusan tentang diterima atau tidaknya suatu masukan (Bloom, 2010).

Peserta didik mulai aktif pada tahap middle game, sebab tahap ini merupakan kegiatan belajar dan bekerja secara berkelompok untuk menyelesaikan masalah. Peneliti berkeliling menghampiri tiap-tiap kelompok untuk mengamati perkembangan prosesnya dan memberikan bantuan kepada beberapa kelompok yang tidak aktif dalam kegiatan diskusi. Ketidakaktifan tersebut disebabkan karena peserta didik belum berpengalaman dalam menyelesaikan soal menggunakan langkah pemecahan masalah.

Diakhir kegiatan belajar, peneliti langsung mengambil alih akibat keterbatan waktu. Sehingga pada tahap end game tidak dapat begitu optimal dalam pelaksanaannya. Walaupun begitu, peserta didik antusias memberikan kesimpulan dan menjawab pertanyaan-pertanyaan yang diberikan oleh peneliti.

Magnessen (Hamid, 2011) mengungkapkan bahwa peerta didik belajar 10\% dari apa yang dibaca, 20\% dari apa yang didengar, 30\% dari apa yang dilihat, 50\% dari apa yang didengar, 70\% dari apa yang dikatakan, serta 90\% dari apa yang dikatakan dan dilakukan. Pada kelas kontrol yang diberikan pengajaran menggunakan model pembelajaran konvensional, peserta didik mengingat dan menguasai pelajaran tersebut hanya 20\%, karena hanya mendengarkan saja. Sebaliknya, pada kelas eksperimen yang diberikan pengajaran model Cooperative Problem Solving, peserta didik mengingat dan menguasai pelajaran tersebut sebanyak 90\%. Dengan demikian, peserta didik kelas eksperimen memahami materi tekanan dengan cukup baik dibanding kelas kontrol.

\section{Efektivitas Proses Pembelajaran}

Nilai effect size cohen menunjukkan bahwa pengaruh model Cooperative Problem Solving dalam meningkatkan kemampuan pemecahan masalah peserta didik tentang materi tekanan memiliki efektivitas sebesar 1,89 tergolong tinggi dibanding kelas kontrol, ditandai dengan perolehan rata-rata kelas eksperimen lebih tinggi dibanding kelas kontrol. 
Dengan demikian, dapat disimpulkan bahwa model Cooperative Problem Solving efektif dalam meningkatkan kemampuan pemecahan masalah peserta didik. Hal ini sejalan dengan penelitian yang dilakukan oleh Sari et al (2018) dan Avico et al (2019).

\section{Kesimpulan}

Berdasarkan hasil penelitian, secara umum dapat disimpulkan bahwa model Cooperative Problem Solving efektif untuk meningkatkan hasil kemampuan pemecahan masalah peserta didik pada materi tekanan di SMP Negeri 3 Sungai Raya.

\section{Referensi}

Alieffia, Ziyyan \& Tantri Mayasari. (2018). Profil Kemampuan Pemecahan Masalah Pelajaran Siswa Fisika Siswa MTs. Seminar Nasional Quantum, 2477-1511.

Andita, Dici Rizka. (2016). Keterampilan Pemecahan Masalah dalam Pembelajaran Abad 21. Proceedings International Seminar.

Andrian, Yusuf \& Rusman. (2019). Implementasi Pembelajaran Abad 21 dalam Kurikulum 2013. Jurnal Penelitian IImu Pendidikan, 2(1).

Avico, Indra., AndikPurwanto., \& Desy Anisa Putri. (2019). Pengaruh Pembelajaran Cooperative Problem Solving Terhadap Kemampuan Pemecahan Masalah Fisika Siswa di SMAN 1 Kapahiang. Jurnal Kumparan Fisika, 2(1).

Azizah, Rismatul., Lia Yuliati., \& Eny Latifah. (2016). Kesulitan Pemecahan Masalah Fisika Pada Siswa SMA. Jurnal Penelitian Fisika dan Aplikasinya (JPFA), 5(2), 44-50.

Badan Nasional Pendidikan. (2010). Paradigma Pendidikan Nasional Abad XXI. BNSP versi 1.0. Retrieved Februari 15, 2016, from https://www.bsnp-indonesia.org/id/wp-content/Laporan BSNP2010.pdf

Coleman, J.M., E.M.McTique., \& L.B. Smolkin. (2010). Elementary Teachers Use of Graphical Representations in Science Teaching. Journal Science Teacher Education, 22, 613-643.

Dewi, I.N., S. Poedjiastoeti., \& B.K. Prahani. (2017). ELSII Learning Model Based Local Wisdom to Improve Students' Problem-Solving Skills and Scientific Communication. International Journal of Education and Research, 5(1), 107-118.

Hamid, S. (2011). Metode Edutaitainment. Yogyakarta: Diva Press.

Heller, P., \& Heller, K. (2010). Cooperative Problem Solving in Physics A User's Manual. (pp 6). University of Minnesota.

Ikhwanuddin, Jaedun. A., \& Purwantoro. (2010). Problem Solving dalam Pembelajaran Fisika untuk Meningkatkan Kemampuan Mahasiswa Berfikir Analitis. Jurnal Kependidikan, 14(16).

Kemendikbud. (2014). Konsep dan Implementasi Kurikulum 2013 (online). https://kemdikbud.go.id/kemdikbud/dokumen/paparan/paparan/\%20wamendik.pdf. Diakses tanggal 11 Agustus 2018.

Kurniati, Dian., Romi Harimuki., \& Nur Aisyah Jamil. (2016). Kemampuan Berfikir Tingkat Tinggi Siswa SMP Di Kabupaten Jember dalam Menyelesaikan Soal Berstandar PISA. Jurnal Penelitian dan Evaluasi Pendidikan, 20(2).

Kulsum, U., \& Nugroho. (2014). Penerapan Model Pembelajaran Cooperative Problem Solving Untuk Meningkatkan Kemampuan Pemahaman Konsep dan Komunikasi IImiah Pada Mata Pelajaran Fisika. Unnes Physics Education journal, 3, 74-78.

Lestari, Karisma. (2019). Penerapan Penyelesaian Masalah Heller Untuk Meningkatkan Kemampuan Menyelesaikan Soal Materi Gerak Lurus. Jurnal Penelitian Pendidikan Khatulistiwa.

Lona, Defru Yanto., Kamaludin., \& Fihrin. (2013). Analisis Hirarki Pemahaman Siswa Kelas XA SMA Negeri 5 Palu Pada Materi Hukum Newton. Jurnal Pendidikam Fisika Tadulako, 1(1), 2338-3240.

Markawi, Napis. (2015). Pengaruh Keterampilan Proses Sains, Penalaran, dan Pemecahan Masalah Terhadap Hasil Belajar Fisika. Jurnal Formatif, 3(1).

Masfuah, Siti., \& Ika Ari Pratiwi. (2018). Pentingnya Kemampuan Pemecahan Masalah dan Karakter Bersahabat. Prosding Seminar Nasional-Penguatan Pendidikan Karakter Pada Siswa Dalam Menghadapi Tantangan Global. 
Mukminan. (2014). Peningkatan Kualitas Pembelajaran Pendayagunaan Teknologi Pendidikan. Seminar Nasional Pendidikan

Murtiningsih, Siti. (2004). Pendidikan Alat Perlawanan. Yogyakarta: Resist Book.

Nurcahyo, Agung Wahyu., Wartono., \& Lia Yuliati. (2017). Kemampuan Pemecahan Masalah Hukum Gerak Newton Mahasiswa Melalui Pembelajaran Cooperative Problem Solving. Jurnal Pendidikan, 2(7).

OECD. (2017b). PISA 2015 Result Volume V: Collaborative Problem Solving. http://www.oecd.org/publications/pisa-2015-results-volume-v-9789264285521-en.html.

Prasetyoningrum, Rahma., J.S. Sukarjo., \& Nanik Dwi Nurhayati. (2014). Penerapan Pembelajaran Cooperative Problem Solving (CPS) untuk Meningkatkan Kreativitas dan Prestasi Belajar Pada Materi Pokok Hidrolisis Garam Siswa Kelas XI IPA 1 Semester Genap SMA Negeri 2 Sukoharjo Tahun Pelajaran 2013/2014. Jurnal Pendidikan Kimia, 3(3)

Prastiwi, Merry Dwi. (2018). Kemampuan Pemecahan Masalah Pada Siswa Kelas VII SMP. E-Jurnal-pensa, 6(2).

Ramadhan, Tio. (2010). Penerapan Discovery Learning Berbantuan Phet Simulation Untuk Meningkatkan Hasil Belajar Listrik Statis di SMA. Jurnal Penelitian Pendidikan Khatulistiwa, 9(4).

Ratnaningdyah, D. (2017). Melatihkan Kemampuan Pemecahan Masalah Melalui Pembelajaran Fisika dengan Model Cooperative Problem Solving (CPS). Jurnal IImu Pendidikan Fisika, 2.

Sari, Vionna Junita., Connie., \& Eko Swistoro. (2018). Upaya Peningkatan Kemampuan Pemecahan Masalah dan Hasil Belajar Peserta Didik Melalui Penerapan Metode Cooperative Problem Solving. Jurnal Kumparan Fisika, $1(1)$.

Slameto. (2015). Pembelajaran Berbasis Riset Mewujudkan Pembelajaran yang Inovatif. Jurnal Satya Widya, 31(2). Sujarwanto,. E. , A. Hidayat., \& Wartono. (2014). Kemampuan Pemecahan Masalah Fisika Pada Modeling Instruction Pada Siswa SMA Kelas XI. Jurnal Pendidikan IPA Indonesia, 3(1).

Susiana, Nora., Lia Yuliati., \& Eny Latifah. (2017). Analisis Pembelajaran Berdasarkan Profil Kemampuan Pemecahan Masalah Fisika Siswa Kelas X SMA. Prosiding Seminar Nasional. http://research-report.umm.ac.id/index.php/.

Taale, K.D. (2011). Improving Physics Problem Solving Skills of Students of Somaya Senior High Secondary Technical School in The Yilo Krobo District off Eastern Region of Ghana Journal of Education and Practice, 2(6), 8-20.

Trisnawati, Resty. (2017). Pengaruh Model Cooperative Problem Solving Terhadap Hasil Belajar Pada Materi Kelarutan dan Hasil Kali Kelarutan. Jurnal Penelitian Pendidikan Khatulistiwa

Wagner, T. (2010). Overcoming The Global Achievement GAP (online). Cambridge, Mass: Harvard University. 